\title{
An Overview of the Economic Situation of Bangladesh during the Pandemic Caused by COVID-19
}

\author{
Prof. Dr. Mohammed Shakhawat Hossain \\ Principal, Daffodil Institute of IT \\ Md. Mamonur Rashid \\ Lecturer, Department of Business Administration, Daffodil Institute of IT
}

\begin{abstract}
Like other countries in the world Bangladesh has been immeasurably being affected by the longest coronavirus pandemic ever seen by the world. Corona has given a very deep stripped in every sector of the economy of Bangladesh, could largely contributed to the economy as well as of the society. However, it is not that only the economic condition was declined in rather the impact of the new normal was diversified in the different sectors. Economic sectors, Specially RMG, garments, export-import oriented business were largely affected by the pandemic because of the high dependency of the external buyers and resources, either the sector was manufacturing or merchandising. In this new normal age, the small and medium enterprise (SME), lower capital entrepreneur and as well as the banking sector, service industry were also highly disrupted. In exception a milestone role played our wage earners heroes who sent remittances with record amount Bangladesh. Simultaneously, in this situation, the ecommerce platform, IT industry, virtual world and mobile financial services (MFS) have introduced a positive impact on our economy. So, pandemic challenge has come with new learning, new concept and new phenomena for new economy that can be defensed and conquered by giving a huge effort of every individual, organization as well as the keen integration of the state government.
\end{abstract}

Keywords: Coronavirus, Economic condition, COVID-19, Export-Import, Entrepreneur FDI, MFS, New normal age, Pandemic Situation.

DOI: $10.7176 / \mathrm{EJBM} / 14-2-03$

Publication date: January $31^{\text {st }} 2022$

\section{Introduction}

The unseen carnival ghost which started from the Wuhan province of China has already been captured all over the world and completed its first and $2^{\text {nd }}$ wave by destroying almost every sector of humanity. The irrespective of local, national, international, and even global business are going to the door of ruins. The COVID-19 has caused an unbelievable negative impact on humanity, society, and of the overall economy of the globe including Bangladesh. SARS detrimental virus belongs to the family of coronavirus. The world health Organization (WHO) named the virus a novel coronavirus (COVID-19). In Bangladesh, the severity of the infections and deaths are now more detrimental than that of the first wave and as a result the business community, the export-import oriented industries, businesses related with pen, paper and education are passing their ever-worst time. Exceptionally, some IT and online-virtual industries have been playing very positive roles for the economy. The human killer outbreak east to west, south to the north more than 200 countries in the world. (Uddin et.al. 2020)

This outbreak is considered as a Public Health Emergency of International Concern and recognized as a pandemic by the World Health Organization on 11 March 2020. Hundreds of thousands of global, multinational organizations collapsed, millions of people become unemployed, and thus the result is created millions of unexpected social imbalance, lockdown, isolation, and quarantine have been broken the norms of society. Schools, colleges, and university students due to the prolonged broken down study become puzzled and hopeless and in Bangladesh, the scenario is the same like other countries (WHO, 2020). According to Prothom Alo (2020), the suicidal and divorce Rate increased almost $50 \%$ by 2020 compared to the previous year. So, a tremendous social and economic breakdown has been realized.

\section{Objectives of the Study}

This study focuses on an economic disruption of Bangladesh during the pandemic. The purpose of this research is to describe the impact of COVID-19 in this country as well as the overall economy. To accomplish this empirical study, multiple sectors have been surveyed which either currently have economically or socially affected or both. The research shows tremendous potential for recovery of the economic sector in Bangladesh and reveals some of the key barriers to progress as well. The objectives of this study are comprised of:

- To know the insight of economic environment of Bangladesh during Pandemic.

- To find out how much the economic environment affected by COVID-19.

- To know the most affected economic sectors and the measures taken to overcome the situations. 


\section{Research Methodology}

The study is exploratory in nature. Both primary and secondary data collected from different sources like, newspapers, journals, articles, and from other relevant authentic sources. The primary data were collected from In-depth interviews by using an unstructured questionnaire. And by a face-to-face conversation with different levels of audiences.

The three in-depth interviews were made on different economic issues with the chairman of the Security \& Exchange Commission (SEC), the president of Dhaka Chamber of Commerce and Industry (DCCI), the Chairman of the daffodil family, and CEO of DF. In this study, Nvivo software was used to justify the literature reviews, interviews and to identify the most focal points and to establish conceptual model.

\section{Literature Review}

According to the statement of WHO (2020), coronavirus, the killer of humanity, belongs to family of different viruses like MERS, SARS and COVID-19. Among all COVID-19 was found one of the most ferocious for human being and already has created severe threaten by causing the death of about 3 million people all over the world. This contaminated virus mostly attack to old people who have some health disease and have lack of immune power. They also have stated that by washing hands with soap with water and by using alcoholic hand sanitizer. It can be safe and also need to be keep the distance of 1 mitre ( 3 feet) in between two persons. UNDP (2020) depicts that due to pandemic it has been created a devastating toll of socio-economic environment and government have been trying and pumping by creating a budget of $\$ 11.00$ trillion and giving the highest priority. Economists predict that the GDP levels will not return to pre-Covid19 levels until 2023. Those low to medium development countries will be hit the hardest, not just economically, but also socially. The people living in those countries are on the brink. The impact of the coronavirus pandemic has put enormous strain on world economies and for the first time in 30 years has sent human development into reverse. In 2020, as many as 100 million more people could fall into extreme poverty (UNDP), while 270 million people are in danger of acute food insecurity (WFP, 2020). Every day, people are losing jobs and income, with no way of knowing when normality will return. Small island nations, heavily dependent on tourism, have empty hotels and deserted beaches (UNDP, 2020). The International Labor Organization estimates that 400 million jobs could be lost. In compare to the World Bank (2020) statement to the declination of remittance by US\$ 110 billion where as in Bangladesh the remittance flow was very encouraging and the amount was more than previous year. It is very much shocking that millions of permanent and temporary employees were jobless and the result is a huge financial crisis of the respective families, the livelihoods as well as educations (Mathieu Despard. Et. al., 2020) ( Rene Pana-Cryan. Et. al., 2020)

According to Statista (2020) the best-case scenario in 2020, the monetary loss of global Gross Domestic Product (GDP) is expected to be about 76.7 billion U.S. dollars due to the coronavirus (COVID-19) outbreak. In the worst-case scenario, the global GDP is predicted to lose about 346.98 billion U.S. dollars in the next six months. (Statista, 2020) Indeed, the virus spreads around the globe, the greater the concern over not just our health, but our livelihoods. The IMF shows that Brazil is the most affected country to increase the unemployment problem around the world. Gradually Italy, Canada, the USA, France, UK, Germany, Japan, and other countries increase the unemployment problem for Corona (Lora Jones. et. al., 2020). World economies struggling with rising unemployment shows the following table-01 compared between year of 2020 and year of 2019 .

Table-01: The world unemployment scenario between 2020- 2019.

\begin{tabular}{|c|c|c|c|}
\hline \multirow{2}{*}{ Country name } & \multicolumn{2}{|c|}{ Unemployment rate } & \multirow{2}{*}{ Compared between 2020 to 2019 } \\
\cline { 2 - 3 } & In 2020 & In 2019 & $+1.5 \%$ \\
\hline Brazil & $13.4 \%$ & $11.9 \%$ & $+1.1 \%$ \\
\hline Italy & $11 \%$ & $9.9 \%$ & $+4 \%$ \\
\hline Canada & $9.7 \%$ & $5.7 \%$ & $+5.2 \%$ \\
\hline United States & $8.9 \%$ & $3.7 \%$ & $+0.4 \%$ \\
\hline France & $8.9 \%$ & $8.5 \%$ & $+1.6 \%$ \\
\hline United Kingdom & $5.4 \%$ & $3.8 \%$ & $+1.2 \%$ \\
\hline Germany & $4.3 \%$ & $3.1 \%$ & $+0.9 \%$ \\
\hline Japan & $3.3 \%$ & $2.4 \%$ & \\
\hline
\end{tabular}

Source: International Monetary Fund (IMF), 2020 
Table-02: World GDP Scenario during the pandemic

\begin{tabular}{|c|c|c|c|}
\hline \multirow{2}{*}{ Countries Name } & \multicolumn{2}{|c|}{ Estimate } & \multicolumn{2}{|c|}{ Projections } \\
\cline { 2 - 4 } & $\mathbf{2 0 2 0}$ & $\mathbf{2 0 2 1}$ & 2.5 \\
\hline USA & -3.4 & 5.1 & 3.1 \\
\hline Germany & -5.4 & 3.5 & 4.1 \\
\hline France & -9.0 & 5.5 & 3.6 \\
\hline Italy & -9.2 & 3.0 & 4.7 \\
\hline Spain & -11.1 & 5.9 & 2.4 \\
\hline Japan & -5.1 & 3.1 & 5.0 \\
\hline United Kingdom & -10.0 & 4.5 & 4.1 \\
\hline Canada & -5.5 & 3.6 & 5.6 \\
\hline China & 2.3 & 8.1 & 6.8 \\
\hline India & -8.0 & 11.5 & 4.0 \\
\hline
\end{tabular}

Source: IMF, world economic outlook (2021)

\section{Economic Scenario of Bangladesh}

The economic condition has drastically affected due to the attack of coronavirus all over the world as well as Bangladesh. Around 9 million people have already lost their jobs, the GDP of the countries is around zero and even to some extend negative (ADB, 2020). So, the total economic condition all over the world, including Bangladesh, is measurably affected. In Bangladesh, the government of China is providing monetary and specialized facilities to develop ongoing projects such as Padma Bridge, Padma Rail Link, Karnaphuli Road Tunnel, and Dhaka Sustainable Urban Transport Project but this corona pandemic has a bad impact on those megaprojects. Bangladesh has achieved GDP growth at more than 6 percent on average during the last decade. From the financial year 2015-2019, the GDP growth were circulated 7 to 8 percent and even in 2018-2019, it was 8.15 percent. Whereas, in FY 2019-2020 it reached 5.24\% which indicates how devastating the way corona affected our economy though it is one of the highest growth records of the world GDP (BER-2020).

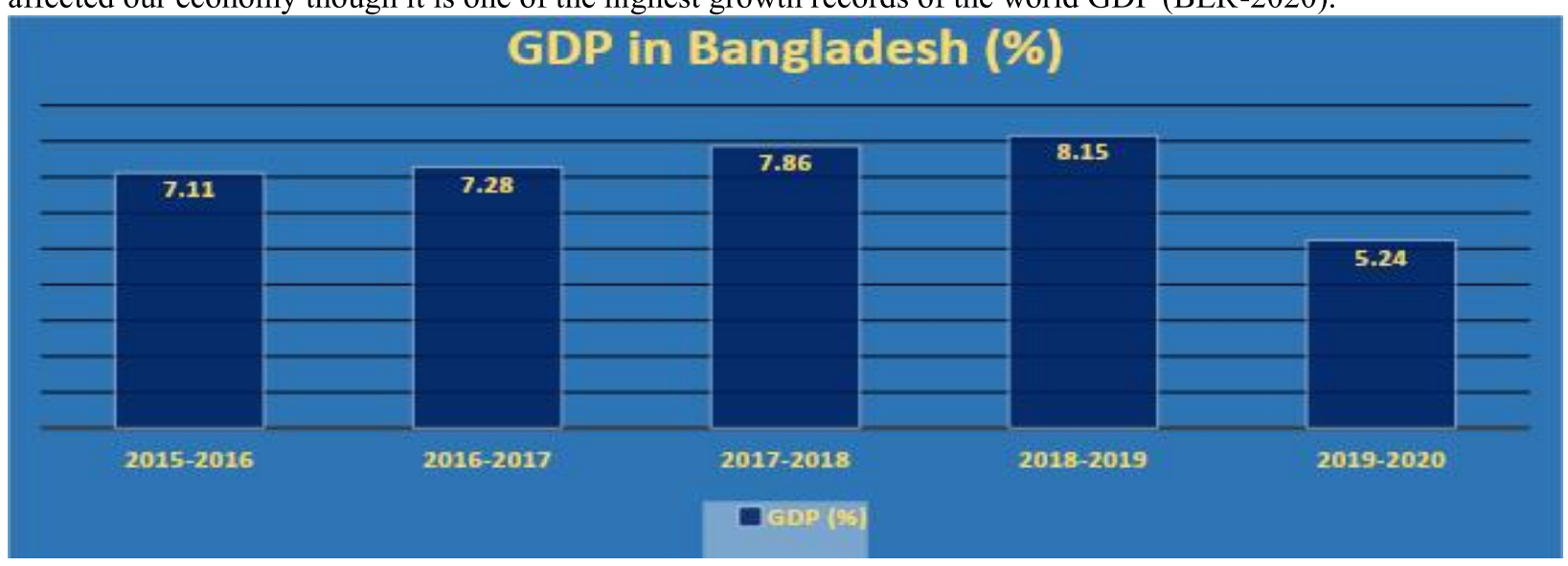

Figure-01: Year-wise GDP in Bangladesh shows in the bar chart.

BER (2020) also shows that historically three leading sectors in Bangladesh, Agricultural, Industrial and Services sector have been playing a very important role in the economic development by providing more than $95 \%$ of the total GDP where, Agriculture 40.6\%, Industry 20.4\% and Service sectors 39\% and all sectors were drastically affected by this pandemic.

Asian Development Bank has closely been monitoring the economic and social scenarios of Bangladesh and from their investigation, it has been found the following picture (in table-3) in the different sectors of Bangladesh.

Table-03: Economic loss and unemployment scenario of Bangladesh.

\begin{tabular}{|l|l|l|l|}
\hline SL No. & \multicolumn{1}{|c|}{ Particulars } & \multicolumn{1}{|c|}{ Amount (\$) } & \multicolumn{1}{|c|}{ Job Lost (Unit) } \\
\hline 1 & Bangladesh will lose approximately its GDP & $\$ 3000$ million & \multicolumn{1}{|c|}{} \\
\hline 2 & Individuals lost their jobs during the pandemic & - & $90,00,000$ people \\
\hline 3 & Exchange and Open administrations & $\$ 1140$ million & 201106 people \\
\hline 4 & The Travel Industry & $\$ 510$ million & 50,000 people \\
\hline 5 & Development and Utilities & $\$ 400$ million & 1180000 people \\
\hline 6 & Transport Administration & $\$ 334$ million & 67,000 people \\
\hline
\end{tabular}

Source: Asian Development Bank (2020)

The Asian Development Bank (2020) predicts that Bangladesh will lose approximately $\$ 3000$ million in its 
GDP at the same time around 9 million individuals will lose their jobs. Specifically, It is noteworthy that different sectors of the economy of Bangladesh have been affected individually such as exchange and open administrations would lose by $\$ 1140$ million and 201106 individuals, separately by agribusiness $\$ 637$ million, 458000 individuals, the travel industry $\$ 510$ million, 50,000 people, development and utilities $\$ 400$ million, 1180000 people and transport administration $\$ 334$ million, 67,000 people ADB (2020).

According to the country's commerce minister, In Bangladesh garments sector, more than 2.6 billion orders have been withdrawn and new cancellations are coming up Choudhury S. R. (2020) revealed, Bangladesh piece of clothing manufacturing company probably going to face major problem to pay 4.1 million laborers who are low paid workers.

BGMEA (2020) refers that, about $\$ 2.67$ billion worth of requests in 966 manufacturing plants have just been suspended, and it influences around 1.96 million specialists so far. The current scenario of the total garments sector in Bangladesh is shown below:

Table-04: Comparative Statement on Export of RMG \& Total Export of Bangladesh

\begin{tabular}{|c|c|c|c|}
\hline Year & Export of RMG & Total Export of BD & $\begin{array}{c}\% \text { of RMG's to Total Export } \\
\text { (Value in Million USD) }\end{array}$ \\
\hline $2016-2017$ & 28149.84 & 34655.90 & 81.23 \\
\hline $2017-2018$ & 30614.76 & 36668.17 & 83.49 \\
\hline $2018-2019$ & 34133.27 & 40535.04 & 84.21 \\
\hline $2019-2020$ & 27949.19 & 33674.09 & 83.00 \\
\hline
\end{tabular}

Source: BGMEA/Export-Performances (2020)

According to the given data shows that the Export of RMG and the total export of BD is declining in FY 2019-2020 other than the previous Fiscal Year due to the COVID-19 pandemic.

Table-05: Category wise import payment in Bangladesh

\begin{tabular}{|l|c|c|}
\hline \multicolumn{1}{|c|}{ Major Commodities } & $\mathbf{2 0 1 8 - 1 9}$ & $\mathbf{2 0 1 9 - 2 0 2 0}$ \\
\hline 1. Food Grains & $\mathbf{1 2 7 2}$ & $\mathbf{1 5 0 6}$ \\
\hline 2. Milk \& cream & 336 & 327 \\
\hline 3. Spices & 315 & 968 \\
\hline 4. Oil seeds & 653 & 1448 \\
\hline 5. Edible oil & 1718 & 590 \\
\hline 6. Pulses all sorts & 411 & 629 \\
\hline 7. Sugar & 647 & 662 \\
\hline 8. Clinker & 716 & 468 \\
\hline 9. Crude petroleum & 930 & 5084 \\
\hline 10. POL & 5731 & 2215 \\
\hline 11. Chemical & 2222 & 150 \\
\hline 12. Pharmaceutical products & 146 & 948 \\
\hline 13. Fertilizer & 1120 & 616 \\
\hline 14. Dyeing, tanning etc. materials & 693 & 2323 \\
\hline 15. Plastics and rubber articles thereof & 2383 & 2657 \\
\hline 16. Raw cotton & 2932 & 1677 \\
\hline 17. Yarn & 2113 & 4220 \\
\hline 18. Textile and articles thereof & 4985 & 724 \\
\hline 19. Staple fibre & 811 & 3897 \\
\hline 20. Iron, steel and other base metals & 4325 & 3715 \\
\hline 21. Capital machinery & 5147 & 10503 \\
\hline 22. Others & 12785 & $\mathbf{4 5 6 7 5}$ \\
\hline Subtotal : & $\mathbf{5 2 3 9 1}$ & 3025 \\
\hline Imports of EPZ & 3669 & $\mathbf{4 8 7 0 0}$ \\
\hline Grand Total : & $\mathbf{5 6 0 6 1}$ & \\
\hline
\end{tabular}

Source: Statistics Department, Bangladesh Bank (2020).

\section{Remittance}

Dramatically it has been observed that though the Corona pandemic severely affected employment and lots of job opportunities, still the flow of remittance was very encouraging for Bangladesh. According to the report of Bangladesh Bank reveals that the remittance flow from abroad is encouraging during the corona pandemic. More than USD 21,742 million come in the year 2020, overall economy is largely influenced by the remittance. 


\section{Amount (in million USD)}

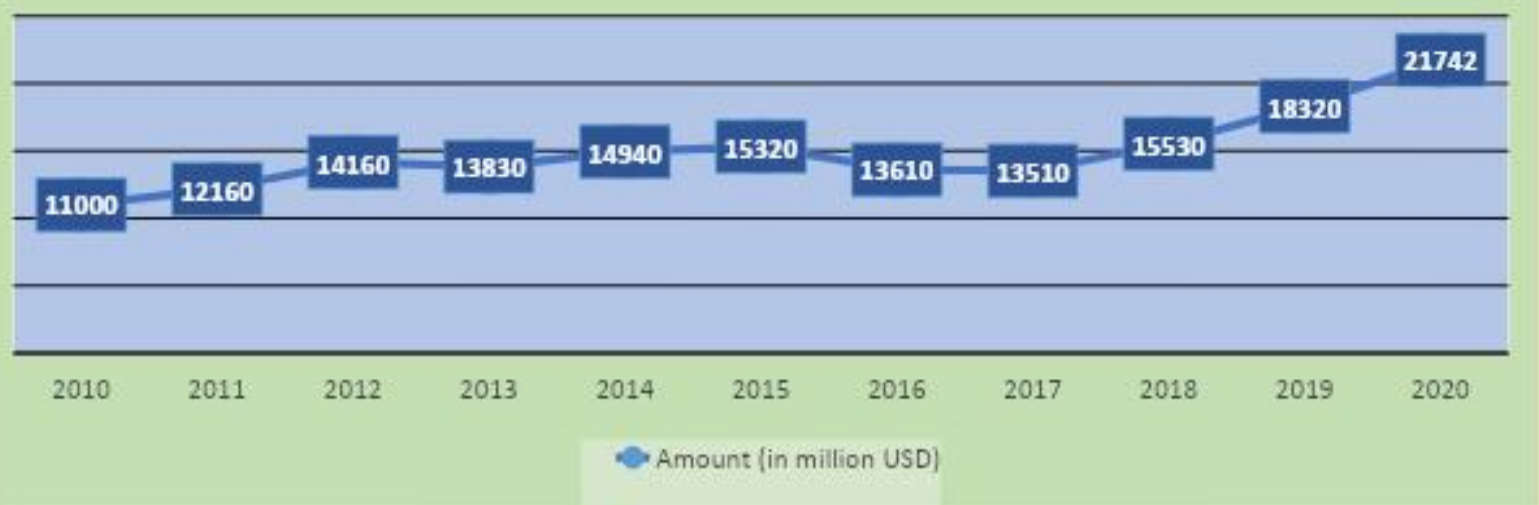

Figure-02: Remittance flow from abroad over the last decade

Around 13 million Bangladeshi's working abroad such as Saudi Arabia, Qatar, UAE, Bahrain, Italy, United States, etc. sent about USD18000 million in FY 2018-19. Figure 3 shows that remittances in Bangladesh reduced to 1638.53 USD Million in January from 1691.68 USD million in December of 2019 (Karim \& Islam, 2020)

Bangladesh Economic Review-2019 shows that the Economic Sectors in Bangladesh, the Service sector is generally important. The commitment of the administration division to the GDP is about $53 \%$.

\section{Capital Market during the pandemic}

The closer view of the impact of Covid-19 on the month-wise index of Dhaka Stock Exchange (DSE), Dhaka Stock Exchange's monthly turnover and month-wise market capitalization of DSE. Since the government announced general vacations to control pandemics, the market remained closed from 25 March 2020 to 30 May 2020. However, after a government declaration of sizeable stimulus packages, BB's expansionary monetary policy, strong wage-earner growths, and the resumption of major economic activities, the market recovered its confidence and began to bounce back.

Month-wise index of Dhaka Stock Exchange increased gradually to 5479.62 in April 2021 from 4008.29 in March 2020.

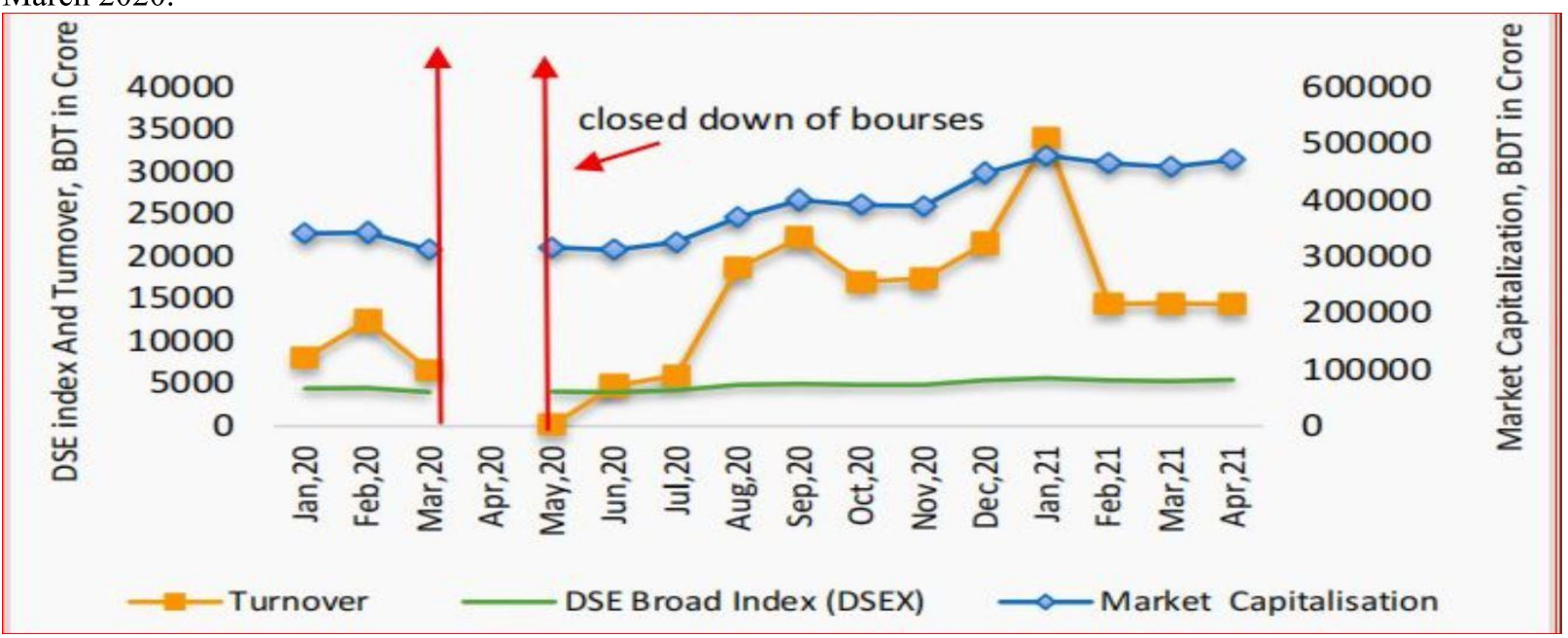

Source: Bangladesh Bank Special Report, 2021

Figure-03: Trend in market capitalization, DSE index and Turnover

A growing trend is observed from May 2020 and the monthly turnover peaked at BDT 33958.76 crore in January 2021. Later, it stood at BDT 14377.27 crore in April 2021. Therefore, there has been a growing trend from May 2020 in terms of month-wise Market Capitalization of DSE, and its value stood at BDT 470712.8 crore in April 2021. To improve the liquidity condition in the capital market, the BB and related regulatory bodies took several initiatives such as: (i) the BB has asked all scheduled banks to create a special investment fund of BDT 2.0 billion for investment in the stock market in addition to banks' stock market exposure limit; (ii) banks can avail financial support from BB through long term repo (iii) the BSEC approved Investment Corporation of Bangladesh's (ICB) BDT 20.0 billion fund for capital market investment. 
Insight of tourism and hospitality sector of Bangladesh

Table-06: Revenue will decline from the tourism sector of Bangladesh

\begin{tabular}{|c|l|c|}
\hline SL No. & \multicolumn{1}{|c|}{ Particulars } & Amount (\%) \\
\hline 1 & The best-case scenario & $0.001 \%$ \\
\hline 2 & The moderate case scenario & $0.002 \%$ \\
\hline 3 & The worst-case scenario & $0.003 \%$ \\
\hline
\end{tabular}

Sources: Asian Development Bank (2020)

According to The Asian Development Bank (ADB) (2020), the revenue percentage of the tourism sector will decline by $0.001 \%$ in the best-case scenario, $0.002 \%$ in the moderate-case scenario, and $0.003 \%$ in the worst-case scenario.

Tounta P. (2020) depicts that among the most devastating sectors during a pandemic are tourism and hospitality management sectors all over the world. Due to over restrictions of using airports and other centers of mass gathering. Similarly, travel agencies constitute a fragmented sector in Bangladesh and owing to COVID-19. Bangladesh is going to face an economic loss of more than Tk. 3 billion. More than half a million people, who are directly or indirectly employed in the tourism and hospitality industry, are going to face the risk of losing their jobs.

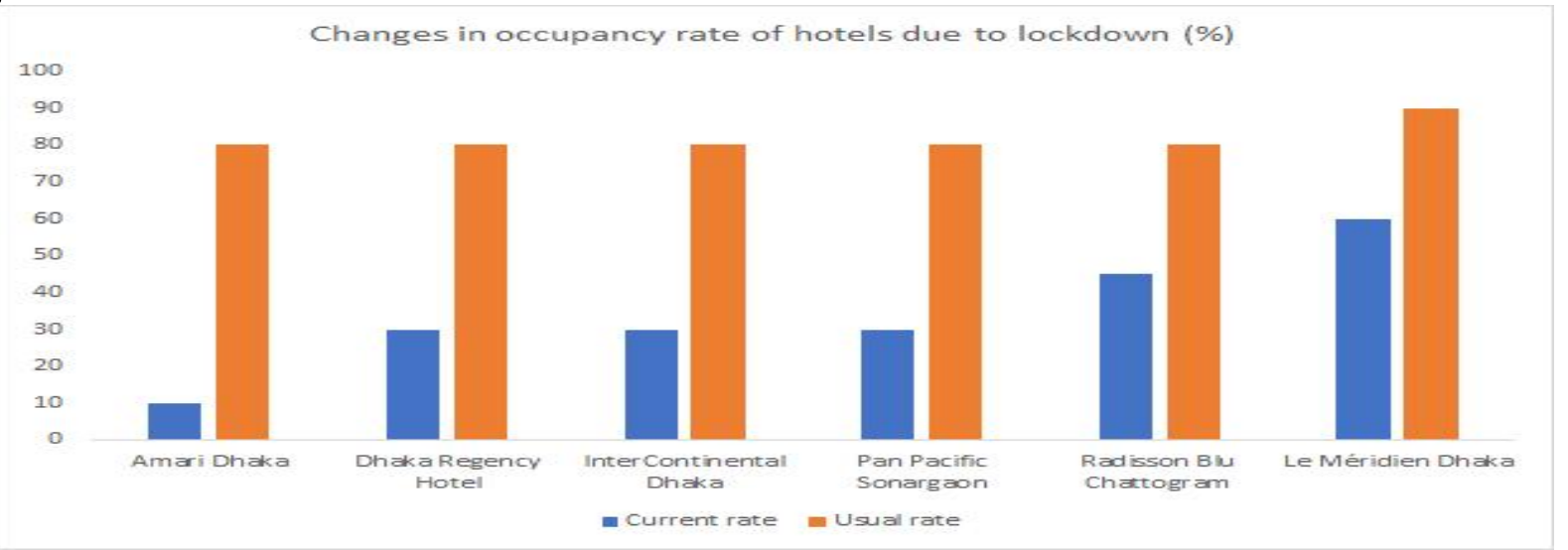

Figure 04: COVID-19 impact on the occupancy rate of luxury hotels.

Development of Tourism Tourism is one of the most promising sectors for Bangladesh with its huge natural beauty, heroic historical background, and archaeological resources (Das \& Chakroborty 2012). Bangladesh is a country of natural beauty. It has lot of tourism places. These places are of different interest like beaches, historical places, archaeological sites, religious palaces, forests and jungles, etc.

In this way, Service sectors contribute to the development of the national economy. There is an idle interest for administrations in Bangladesh. To indicate the need for administrations for the massive populace of Bangladesh, such areas are to be opened for private business people with required control. The gigantic commitment of the administration part and an expanding pattern in that have assumed a significant job in high development of GDP. Due to COVID-19 Pandemic, the service sector might be impacted very badly. At least 12-15 international chain five-star hotels are situated in Bangladesh. Not only that, more than 600 three and two-star unknown hotels and motels are located all over Bangladesh. This business helps many people to earn. The world will face a loss of USD 97.05 billion if this pandemic continues according to Pacific Asia Travel Association's Bangladesh chapter, till May 2020, in the tourism sector.

\section{Insight of e-commerce sector of Bangladesh}

The growth of e-commerce during the pandemic in Bangladesh, unlike other sectors, had taken the full opportunities of the novel corona pandemic, even in Bangladesh.

Table-07: The following table is reflecting the growth picture of the e-commerce sector of Bangladesh.

\begin{tabular}{|c|l|l|}
\hline SL. No. & \multicolumn{1}{|c|}{ Particulars } & \multicolumn{1}{|c|}{ Amount } \\
\hline 1 & Current sales increased by & $70 \%$ to $80 \%$ \\
\hline 2 & The E-commerce market in Bangladesh has exceeded & USD 1500 million \\
\hline 3 & Expected to reach in this year & USD 2000 million \\
\hline 4 & Expected to reach in the year 2023 & USD 3000 million \\
\hline 5 & $\begin{array}{l}\text { Women entrepreneurs selling products on Facebook and other online-based } \\
\text { platforms. }\end{array}$ & 4 lakh \\
\hline 6 & People will be employed in Bangladesh e-commerce in the next five years. & 5 lakh \\
\hline 7 & The e-commerce or online shopping market across the country & TK 6,000 crore \\
\hline
\end{tabular}

Source: New Age, 2020 


\section{The scenario of the e-commerce Business Sector}

The ongoing coronavirus pandemic has locked the entire world's business homes but that does not mean the demands have gone from the market. The customers have adjusted to the situation and shop online and for that, the e-commerce sector is growing around the world. The sector is also flourishing in Bangladesh and is expected to hit USD 3000 million marks by 2023 (New Age, 2020). Local customers in the COVID-19 pandemic are now online. As a result, e-commerce is growing around the globe. Online shopping is significantly increasing. Transactions are also increasing. It is known that online sales have increased by $70 \%$ to $80 \%$ compared to the regular time. Millions of people have been employed in this sector. Business is expanding rapidly. (Abir Hasan, 2020)

According to the German-based research institute Statista (2020), the e-commerce market in Bangladesh has exceeded 1500 million US dollars, expected to reach 2000 million dollars this year and 3000 million dollars by 2023. [Abir Hasan (NewAge Youth), 2020]

\section{Mobile Financial Services (MFS) Scenario during the pandemic}

Mobile financial services (MFS) in Bangladesh including bKash, Nagad, Upay, and the likes, have all risen to the occasion, with additional assistance from the Bangladesh Bank and the Government of Bangladesh, to facilitate safe and secure transactions services to, from, and within the country. These are the strong evidence through bKash, which already had a considerable customer base of 40 million, encountering an increase of more than 1.4 million new accounts getting registered from April 6 to April 21 alone. the daily total transactions undertaken through bKash has dropped from approximately TK 9-10 billion to around TK 7 billion during the Covid-19 crisis, with a daily average transaction of TK 7 million counts. (Bangladesh Bank, 2020)

All MFS were providing emergency services like mobile recharge, bill payment, money transfer, and merchant payment for grocery and medicines to its users, bKash, being the single largest mobile financial service provider in the country, has experienced a $144 \%$ increase in daily average remittance transactions with a total of TK 1.38 billion transferred inward from January 1 to April 18, 2020. Moreover, several variegated measures are taken by companies to aid in the best way they can. Upay has integrated corporate social responsibility practices by contributing to various social causes. According to Sydul Khandakar, The Program Director at UPay, an amount of TK 5000 crore has been donated to the Relief Fund of Honorable Prime Minister by Electronic Fund Transfer to fight against Covid-19.

Table-08: Mobile Financial Services (MFS) comparative summary statement of December 2020 and January 2021

\begin{tabular}{|l|c|c|c|}
\hline \multicolumn{1}{|c|}{ Description } & $\begin{array}{c}\text { Amount } \\
\text { January 2020 }\end{array}$ & $\begin{array}{c}\text { Amount } \\
\text { January 2021 }\end{array}$ & $\begin{array}{c}\text { \% Change } \\
\text { (January 2020 to } \\
\text { January 2021) }\end{array}$ \\
\hline No. of Banks currently providing the Services & 16 & 15 & - \\
\hline No. of agents & 981,537 & $1,044,587$ & $6.42 \%$ \\
\hline No. of registered clients in Lac & 809.16 & $1,005.54$ & $24.26 \%$ \\
\hline No. of active accounts in Lac* & 332.94 & 324.13 & $-2.65 \%$ \\
\hline No. of total transaction & $230,090,192$ & $299,234,698$ & $30.05 \%$ \\
\hline Total transaction in taka(in crore BDT) & $42,103.22$ & $57,253.11$ & $35.98 \%$ \\
\hline No. of the daily average transaction & $7,422,264$ & $9,652,732$ & $30.05 \%$ \\
\hline Average daily transaction (in crore BDT) & 1358.17 & $1,846.87$ & $35.98 \%$ \\
\hline Salary Disbursement (B2P) & 1083.61 & $2,189.63$ & $102.1 \%$ \\
\hline Utility Bill Payment (P2B) & 472.02 & 803.12 & $70.15 \%$ \\
\hline Merchant Payment & 627.77 & $1,924.70$ & $206.59 \%$ \\
\hline Government Payment & 152.34 & 132.28 & $-13.17 \%$ \\
\hline
\end{tabular}

Source: Bangladesh Bank, 2020

Despite of all constraints Bangladesh's economy has overcome many hindrances and has been recognized as one of the highest growth countries all over the world and in South Asia, she is number one. During the lockdown situation when being small all sorts of organizations were closed however that time on one side garments and other industries had faced a very critical situation and on another side, by different MFS and financial organizations money flow from surplus to deficit segment was substantially maintained and these people in the remote areas would maintain their daily needs.

The researcher says that the GDP of the country has extremely fallen due to the corona pandemic. It has not only impacted in a short time but also it will impact on the future overall economy. Following the bar chart to show the past decade of GDP growth in Bangladesh. The garments and textile sectors shut down in the very first time of the pandemic lot of causes the reduction of production due to the widespread cancellation of orders from buyers who did not know when their stores would open and who canceled purchases to try to preserve 
cash. Approximately around a $\$ 2600$ million amount of orders canceled by the buyer, nobody knows when this situation would come in the normal position.

Dramatically it has been observed that though the Corona pandemic severely affected employment and other economic factors, however the flow of remittance was very encouraging for Bangladesh. So, a very fantastic situation has been experienced in our economy. Simultaneously as a good amount of remittance has got it has massively supported to GDP and in other economic yardsticks. Unlike the other countries in the world, Bangladesh has shown very positive performance in the context of economic recovery conditions. Among all countries in the world, one of the three highest GDP growth countries is Bangladesh. This is no doubt an outstanding performance for a country like Bangladesh.

\section{Discussion based Nvivo software}

The software instrument, Nvivo, no doubt is one of the very pragmatic and innovative development of exploratory or qualitative research in respect of establishing a new concept, framework and a mind map for a respective study. Especially it is used on unstructured data for preparing a research report.

Unstructured data from interview script, recorded file, social media survey, images and video files and finally the data from literatures are analyzed in the form of file classification, query wizard, text Search, word Frequency, matrix coding queries, chart, chart Hierarchy, Mind map, concept map and so on. In this study it was used word frequencies, word tree and mind map to find out the mind scenario of the people as well as most emphasized variables addressed in different interview, FGD and in literature.

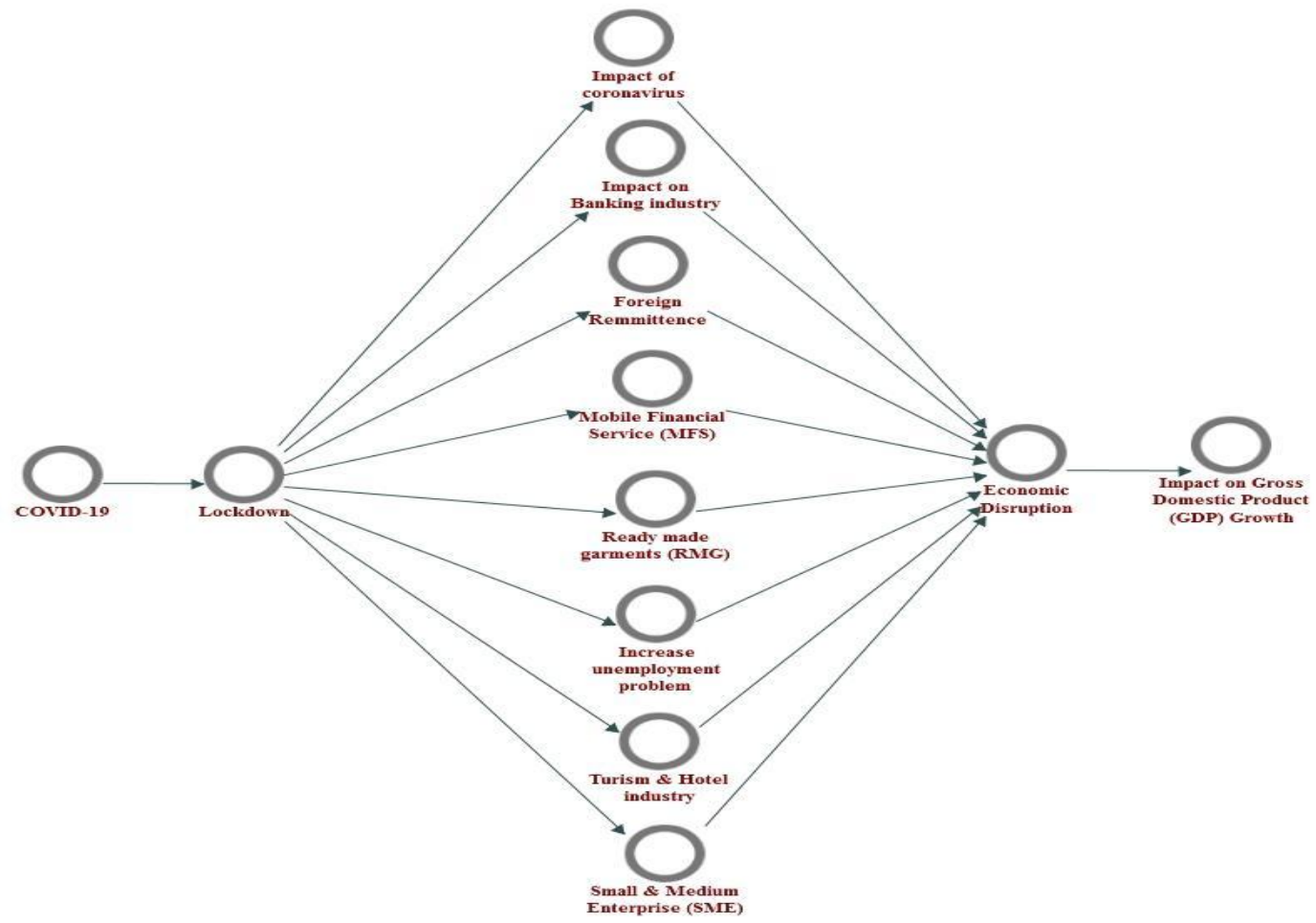

Figure 05: Mind map of the economic factors affected by Corona Pandemic 


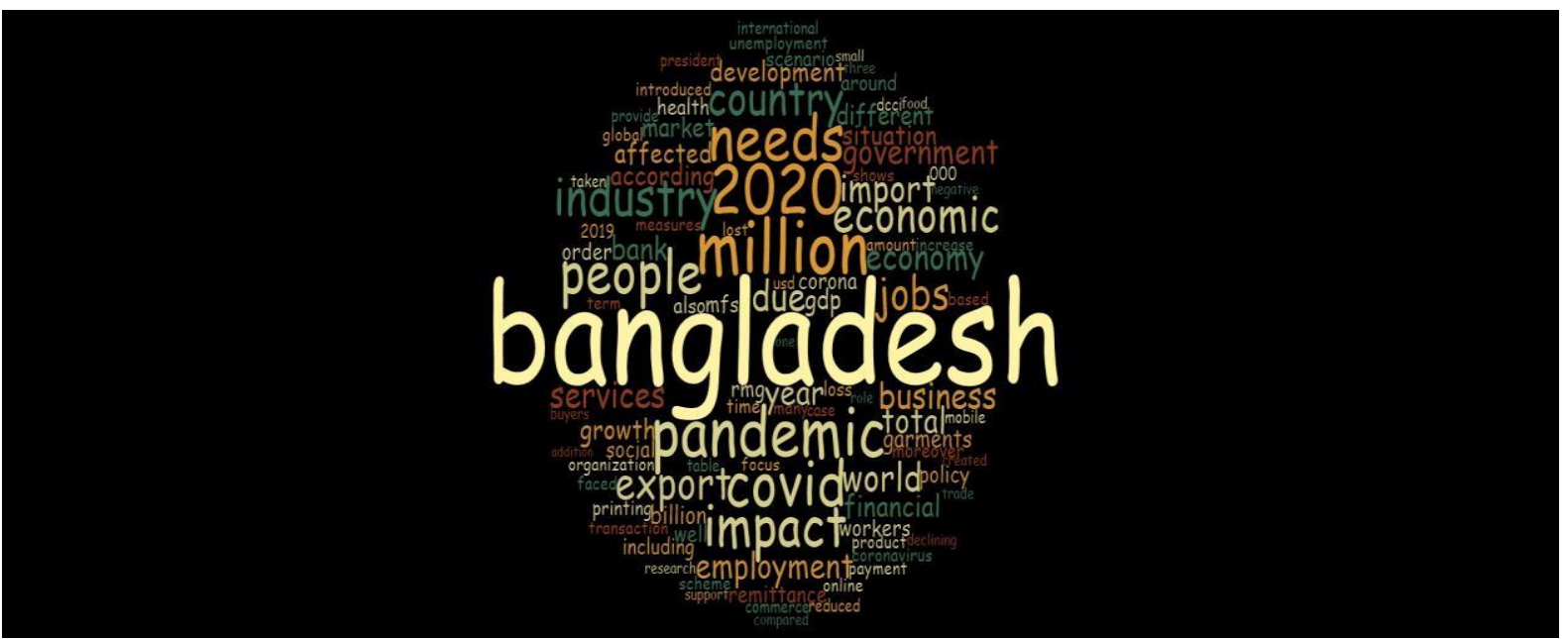

Figure 06: Depiction of the scenario of world Cloud

In the above figure- 5 it has been observed a beautiful cloud of words that used by the experts or also found in the literature frequently mentioned. During the pandemic the economic sectors were highly sufferer and in the context of Bangladesh what sectors mostly affected are emphasized by this word cloud figure. From the word frequency it has been created a mind map where it is being shown the scenario what economic sectors affected due to the corona pandemic and the resulting factor is the negative impact over GDP. In the mind map we see that due to COVID-19 pandemic it was created different sorts of obstacles like, lockdown, shutdown, import-export verniers and so on and thus the contributory economic sectors like garments, RMG, banking, production, tourism and hospitality sectors, employment were strongly disrupted and the ultimate result was the declination of GDP of Bangladesh. It is true that though compare to other countries, even the countries of first world the GDP was more than the expected level and recognized as one of the three best countries in the world. The result of the exception was found in some sectors first one was almost all cancelled export order of RMG and other garments were rescheduled, foreign remittance which was supposed to decline rather increased with record amount, IT and online business were grown in good pace, mobile financial service sectors also played very strong role to fill up the gap between deficit segment and surplus segment in the severe pandemic.

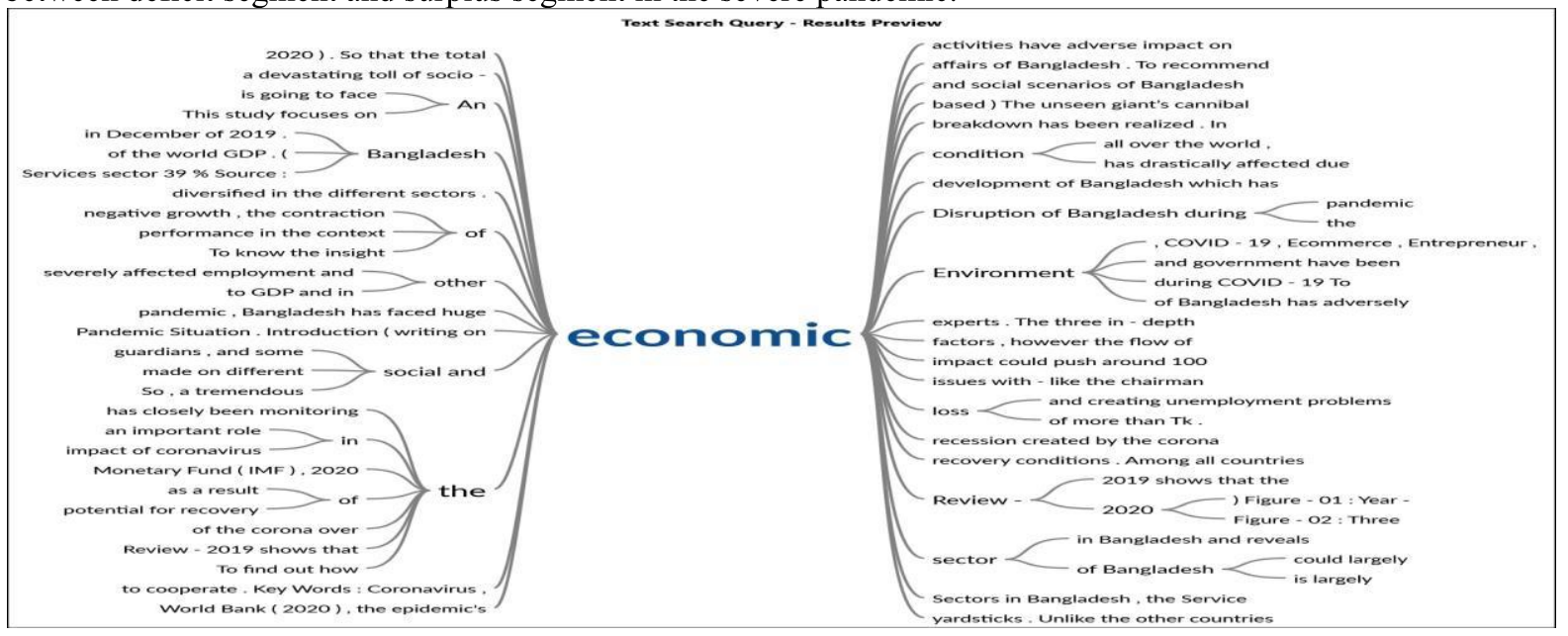

Figure 07: Make the economic tree using text search query.

\section{Analysis and Findings}

After having all the data from literature reviews, interviews and from the oral discussion with different experts apparently it has been created a picture of mixed impact of corona pandemic over the economic arena of Bangladesh and with confidence it can be even said that compare to the rest of the world, even if it is observed the first world economic scenario, Bangladesh is not in that much trouble some position.

\section{Export-import situation}

The mixed position in the sense that if we see the data specially, garments sector which has the largest sector of foreign earnings and employment, it indicates that initially it was at the door of ruin but with the support of government and by regaining the cancelled order it met up disruption position. The total export figure shows that 
in the session 2018 -19 it was $\$ 40.535$ billion and in 2019-20 it \$33.674 billion, however in the RMG sector the declination of export was $85 \%$ to $83 \%$ respectively before and during pandemic (BGMEA, 2020).

It is true that the insight of the import was not up to the mark

The total import in 2018-19 was \$59914 million and in the fiscal year 2019-20 was 54784.70. Total import declined by $8.56 \%$ in FY20 compared to FY19 (Economic Review, 2020). It was adverse in the sense that the declining was in the capital goods and increased in consumer goods and the incremental rate was $13.14 \%$ and capital goods percentage declined by $23.92 \%$.

\section{Capital market scenario}

Another very big economic yard stick of Bangladeshi economies is capital market scenario. Here it is being observed that up to March-2020 the total trading of DSE and CSE, BDT-5568.07 billion and in June 2020 it was BDT 5567.24 billion. The declining scenario was so ignorable $0.015 \%$. However, the positive trend was also observed up to January, '21 when the trading value DSE reached BDT-4245.07 billion where it was only BDT2571.68 billion in March '20 and the rate of increased percent was so encouraging i.e. 58.12\% (Ceicdata.com, 2021)

\section{Unemployment Scenario}

According ADB (2020) the total job lost from different sectors around 9 million. However, from the different interviews, the expert opinion was that the amount of jobless would be three four times more than that of the statement of ADB, if it is considered the seasonal, blue color, street jobbers', and daily labors. This is the curse of Corona pandemic for the people of Bangladesh as well as also for the economy of Bangladesh.

\section{Paper and Printing Business sector}

The paper-based business, mainly printing business, recorded decent growth over the last decade. The annual turnover of the printing business is about BDT.1200 billion. Due to the impact of the COVID-19, it is estimated that the printing industry lost business worth of BDT.40 billion and the percentage is $3.33 \%$.

\section{Scenario of MFS Sector}

No doubt, it was enormous optimistic issue for the economy of Bangladesh when lockdown, isolation, quarantine was so strict for more than a year and there was almost no channel of economy was active but MFS was acted as the blood cell for the poor and deficit segment of informal economic tier. The data from Bangladesh bank has shown that the comparative figure between Jan' 20 to January ' 21 is very much positive and some extend the incremental rate was more than $200 \%$.

\section{Ecommerce and Online Business}

Like other contributory sector, ecommerce as well as virtual business have played very progressive role to reduce unemployment and also created unbounded employment opportunities for young people of Bangladesh. According to OII (2020), about half million freelancers have been working and producing the revenue of $\$ 100$ million and this sort of opportunity has been increasing continuously. ICT division every year arranges the effective training for 65000 young unemployed Bangladeshis who are also being engaged in virtual world. Moreover, ecommerce Business, online Business as well as the transformation of thousands of conventional businesses into online channel are also creating new door of development in the age of new normal.

\section{MFS Market Trend (January 2020 to January 2021)}

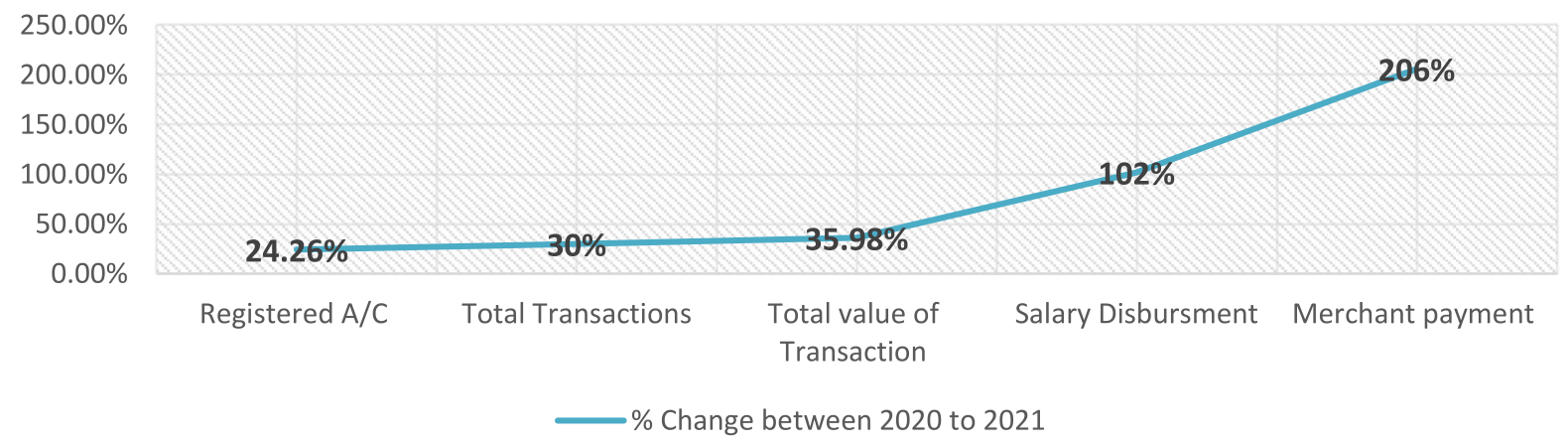

Source: Bangladesh Bank 2020-2021

Figure 08: Picture of MFS market from January '20 to January ' 21 
In the above figure 5 we have seen that during pandemic registered accounts increased by $24.26 \%$, total value of money transaction creased by $35.98 \%$ and merchant payment increased by $206 \%$ which shows very positive indication for the economy. In addition to MFS, few banks have also introduced innovative digital financing solutions to support CMS enterprises which has positive impact on the poverty situation. The collateral free instant digital loan through mobile wallet introduced by the City Bank will expand access to finance for unbanked enterprises and individuals.

\section{Issue of Remittance}

By breaking previous record, the flow of remittance of Bangladesh during pandemic has broken the projections of ADB, World Bank as well as the comments of different experts. Since 2010 the trend of remittance was in positive trend and it was supposed that due to severe pandemic and huge number wage earners returned to home, those who were staying in abroad lost their jobs but still dramatically the flow of remittance increased and created the record. In 2019 immediate before pandemic the amount of remittance was \$18320 million and in 2020 it increased to $\$ 21742$ million and the difference was $\$ 3422$ million which was not matter of joke. This incremental flow obvious worked as the life blood of the rural economy as well as the mainstream economy.

\section{GDP Scenario}

It was very horrible scenario of GDP all over the world due to hostile impact of the COVID-19. No first world countries could gain the positive GDP in 2020 including USA, France, Germany Japan, Russia and even the neighboring country India. However, Bangladesh gained 5.24\% though in FY20 it was 8.15\% in FY19.

The GDP of USA in 2020 was -3.4 , Germany -5.4 , France -9.2 and in India it was -8.0 . So, it is very crucial issue how Bangladesh could achieve this unbelievable result where all giant countries were drastically failed. Moreover, growth of industry, service and agriculture sectors have witnessed a downward trend. Though Bangladesh's economy is performing better while the global economy recorded negative growth, the contraction of economic activities has adverse impact on the job market of the country.

The second wave was further worse the situation. In order to retain employment in this sector, liquidity support through easy access to stimulus packages need to be continued. Considering the COVID-19 a new reality, the Government needs to conduct a survey to assess the sector wise massive job losses and accordingly, policy needs to be framed to boost employment. Moreover, focus needs to be given on boosting the rural economy.

\section{Expert Opinion}

According to the ILO, ADB and local Research Organizations, employment in Bangladesh across all sectors including service, manufacturing and industry has hit hard by the severe impact of the COIVD-19.

Employment in export oriented industries, domestic market orientated industries including trading, transport, hotel, restaurant, tourism and most importantly employment in informal sector faced severe blow.

Though Cottage, Micro, Small and Medium Enterprises (CMSMEs) play important roles in driving the growth, the financial strength of CMSMEs are fragile. Many CMSMEs have already been passing distressed time due to impact of the first wave of the COVID-19.

\section{Comments of different audience}

The different experts and analysts give us their opinion actually how the economic condition will be stabled for the future and we move on in every sectors.

Corona pandemic has drastically affected in every sector of Bangladesh and the economic sector is one of them. In this situation, there are so many obstacles we have faced and still we have been fighting with unpredictable situation. The second wave of the corona pandemic has been blowing on the economy. Several small and medium enterprise has already closed in that case we need to re-think about how we rescue our economic sector from the abnormal situation.

All sectors have been showing the decline position except ecommerce industry and remittance. Flow of the remittance has increased during the pandemic. Where all the countries are facing the dramatic scenarios but Bangladesh has been shown the positive signal from some economic sectors. Audience suggest that the government of Bangladesh should make the monitoring cell to observe the situation and will take immediate decision to protect the economic stability in the future.

\section{Drastically impacted sector in Bangladesh \& Measures taken to overcome}

From this study it was found that one the most affected sectors of Bangladesh during the pandemic were the garments \& import-export sectors. The global spread of COVID-19 and the postponed of dealings by the most of the foreign countries with Bangladesh created a horrible situation as it was the largest foreign earning sector as well as more than 10 million poor people involved with this very sector where more than $80 \%$ are village poor women who can't survive for a month without the support of the organizations. Another very crisis issue was that 
this sector totally depends on the ingredients, related raw materials, and others very important factors of productions which are imported from different countries and simultaneously export to the overseas respected countries. However, in this lockdown, cancellation of orders (some orders were partially reordered by buyers) created big threatening of existence for garments sector. Compare to big organizations the medium and small scale organization who actually run with the supplementary orders of the large ones were totally closed forever with the mountain amount of loses and loans.

To rescue from the ocean of obstacles, government of Bangladesh sanctioned stimulus package of $\$ 8$ billion with minimum rate of interest but the brutal fact was found that the small scale organizations were benefitted a little. At the same time, UNDP has inaugurated the policy for adopting human rights due diligence in the garments industry during the pandemic.

\section{Recommendations}

From the above analysis and the comments and reviews of the experts have revealed the following recommendations. Priority needs to be given on faster implementation of National Single Window to improve our trade facilitation ecosystem, bonded Warehouse policy across all sectors to reduce lead time and cost, reform of foreign exchange regulations and introduction of export credit guarantee scheme. In addition, import policy and industrial policy need to be revised following the COVID-19 impact and ensure better coordination among the policies.

BGMEA and other Business associations need to establish stronger relevant global networks to negotiate with international buyers for better purchasing practices and enforcing standard sales contract. These measures will help curb export order cancellation or suspension, ensure better delivery terms and timely payment to manufacturers. In addition, focus needs to be given on innovation, design and product diversification. Experts also have given emphasis to create new door of investment in the new countries to reduce the dependency of the existing ones.

Informal sector businesses need to be well-protected for the greater interest of the country. Through Government's policy measures transition from informal business to formal business needs to be promoted.

Creating new jobs will be challenging in the new normal practice as well as the rapidly changing technological progress due to the 4th Industrial Revolution. On the other hand about 2.2 million people per year enter into the job market over the next decade. Despite this, many foreigners are dominating the job market filling the vacancy in the technical, managerial and professional levels in diverse industries, corporate houses and MNCs. a targeted cluster-based employment program needs to be taken to arrange jobs for those who have lost jobs due to the pandemic. The pandemic open-up opportunities to digitalize up-stream and down-stream supply chains management of the company including inventory management.

To ensure long-term financial security and to reduce the health expenditure, a universal pension fund scheme and health insurance need to be introduced. A social safety program should be extended to bring the left out people under the financial support scheme.

Government needs to conduct a survey to assess the sector wise massive job losses and accordingly, policy needs to be framed to boost the employment. Moreover, focus needs to be given on boosting rural economy.

\section{Conclusion}

The main contributions of this study are two-fold. First, we highlight the impact of COVID-19 on the economic sectors of Bangladesh and economic scenario of the different sectors. Second, we analyze the data from different authentic sources to find out the current position \& problems and try to give the suggestions how it overcome. Despite these contributions, the study is not without limitations. First, we face the problem to collect data from the different expert, organizations and others due to corona pandemic. Second, the scope is limited to visit the economic sectors of Bangladesh and therefore the communication would be made through online and take the indepth interviews, focus group discussion (FGD) \& some cases face-to-face conversations . It would be worthwhile for future studies. Hopefully, this study contributed to a better understanding of our country's economic conditions and people's willingness to participate in the economy. Its findings can be used as a framework for new research projects and the continuation of Bangladesh's economic development.

\section{Acknowledgement}

The successful completion of the paper was the most embellishing of almighty Allah. The then it has been enjoyed full support and associations of some sage people to whom it must be shown the acknowledgement. Without their support it would be difficult to complete the paper. We would like to express our deepest gratitude and appreciation to honorable President of Dhaka Chamber of Commerce \& Industry (DCCI), Honorable Chairman, Board of Trustees, Daffodil International University \& CEO of Daffodil family (DF). The big gratitude for the honorable Chairman of Bangladesh Security \& Exchange Commission (BSEC). It would not be possible for us to complete this work without their help, advice and suggestions. Also, we would like to express our thankfulness to those 
people who helped us by spending their valuable time in in-depth interviews \& face-to-face conversations. Finally, we are also grateful to some of our Collogues, friends, audience \& economic experts of this sector who helped us to collect information from the different sources.

\section{References:}

1.Abir Hasan (August, 2020); The growth of e-commerce during the pandemic in Bangladesh; NEWAGE Youth; https://www.newagebd.net/article/114200/the-growth-of-e-commerce-during-the-pandemic-in-bangladesh

2.Anamika Barua (2020); The impact of COVID-19 Pandemic: Education sector of Bangladesh; Bangladesh Institute of Peace and Security Studies; https://bipss.org.bd/the-impact-of-covid-19-pandemic-educationsector-of-bangladesh/

3.Bangladesh Bank (2020); Wage earners' remittance inflow; Foreign Exchange Policy Department; https://www.bb.org.bd/econdata/wageremitance.php

4.Bangladesh bank (2020); Financial system; payment and settlement systems; mobile financial services; https://www.bb.org.bd/fnansys/paymentsys/mfsdata.php

5.Bangladesh Bank (2020); Wage Earners Remittance inflows: Selected Country-wise (Monthly); Foreign Exchange Policy Department; https://www.bb.org.bd/econdata/wagermidtl.php

6.Bangladesh Bank (2021); Special Publication; "Covid-19 Pandemic in Bangladesh: Policy Responses and its Impact” https://www.bb.org.bd/en/index.php/publication/publictn/7/38

7.CEICData (2021); Bangladesh Dhaka Stock Exchange: Market Capitalization; ISI Emerging Markets Group Company; https://www.ceicdata.com/en/bangladesh/dhaka-stock-exchange-market-capitalization

8.Daniel Kurt (2020); COVID-19 sharply curtailed the economy, though relief could come in 2021; Investopedia; https://www.investopedia.com/special-economic-impact-of-pandemics-4800597

9.D. P. Bruns et. Al. (April, 2020); COVID-19: Facts, Cultural Considerations, and Risk of Stigmatization; Journal of Transcultural Nursing; https://www.ncbi.nlm.nih.gov/pmc/articles/PMC7324134/

10.Economic world outlook (2021); International Monetary $\quad$ Fund; https://www.imf.org/en/Publications/WEO/Issues/2021/01/26/2021-world-economic-outlook-update

11.Statistics department (Bangladesh Bank-2020); Import payments-Category-Wise https://www.bb.org.bd/econdata/import/categoryimp.php

12.Food and Agriculture Organization of the United Nations (2020); COVID-19 pandemic - impact on food and agriculture; http://www.fao.org/2019-ncov/q-and-a/impact-on-food-and-agriculture/en/

13.Jacopo Dettoni; (2020); Oxford Internet Institute; https://www.fdiintelligence.com/article/77130

14.Karim M.R. Overseas employment and sustainable development goals in Bangladesh: Connectedness, contribution and achievement confusion. Bangladesh Journal of Public Administration. 2020;28(Special Issue):70-71. [Google Scholar]

15.Lora Jones. et. al.(2020); Coronavirus: How the pandemic has changed the world economy; BBC; https://www.bbc.com/news/business-51706225

16.Mathieu Despard. et. al. (July 2020); Brookings; COVID-19 job and income loss leading to more hunger and financial hardship; https:/www.brookings.edu/blog/up-front/2020/07/13/covid-19-job-and-income-lossleading-to-more-hunger-and-financial-hardship/

17.Md. Islam; The Business Standard (2020); Bangladesh ICT sector in Covid world: Impacts and way outs; https://www.tbsnews.net/thoughts/bangladesh-ict-sector-covid-world-impacts-and-way-outs-130945

18.Momotaj. et. al. (2020); COVID-19 and Bangladesh: Socio-Economic Analysis towards the Future Correspondence; Research Gate; https//www.researchgate.net/publication/340936444_COVID19 and Bangladesh Socio-Economic Analysis Towards the Future Correspondence

19. Nawaz Farhin Antara (June, 2020); Covid-19 impacts 95\% households' income; Dhaka Tribune.com;https://www.dhakatribune.com/health/coronavirus/2020/06/20/covid-19-impacts-95households-income

20.New Age (2020); The growth of e-commerce during the pandemic in Bangladesh; https://www.newagebd.net/article/114200/the-growth-of-e-commerce-during-the-pandemic-in-bangladesh

21.Prof. Sarwar Md. Saifullah Khaled (February, 2020); the way Covid-19 is affecting Bangladesh economy; the independent; http://www.theindependentbd.com/post/237519

22.Rene Pana-Cryan. et. al. (June 2020); Economic Security during the COVID-19 Pandemic: A Healthy Work Design and Well-being Perspective; Centers for Disease Control and Prevention; https://blogs.cdc.gov/nioshscience-blog/2020/06/22/economic-security-covid-19

23.Statista (November 2020); Forecasted monetary global GDP loss due to COVID-19, by scenario 2020; Statista Research Department; https://www.statista.com/statistics/1102971/covid-19-monetary-global-gdp-lossscenario/

24.TBS Report; (March, 2020); poultry-sector-stares-over-tk1150-crore-losses; the business standard; https://tbsnews.net/economy/industry/poultry-sector-stares-over-tk1 150-crore-losses-63472 
25.Trading Economics (2020); Remittances in Bangladesh decreased to 1963.94 USD Million in August from 2598.21 USD Million in July of 2020; Bangladesh Remittances; https://radingeconomics.com/bangladesh/remittances

26.The daily star (May 2020); Mobile Financial Services soaring in a pandemic-stricken Bangladesh; https://www.thedailystar.net/toggle/news/mobile-financial-services-soaring-pandemic-stricken-bangladesh1900507

27. UNESCO (2020); UNESCO and Education International calls on governments to consider teachers and school personnel as a priority group in COVID-19 vaccination efforts; unesco.org; https://en.unesco.org/news/unesco-and-education-international-call-governments-consider-teachers-andschool-personnel

28.UNDP (September 2020); Global coronavirus death toll passes 1 million; https://reliefweb.int/report/world/global-coronavirus-death-toll-passes-1-million

29.UNDP (2020); Humanity needs leadership and solidarity to defeat the coronavirus; https://www.undp.org/content/undp/en/home/coronavirus.html

30.Worldometers (2020); countries-where-corona virus-has-spread; www.worldometers.info; https://www.worldometers.info/coronavirus/countries-where-coronavirus-has-spread/

31.Young Minds (September, 2020); corona virus-impact-on-young-people-with-mental-health-needs; youngminds.org.uk; https://youngminds.org.uk/about-us/reports/coronavirus-impact-on-young-people-withmental-health-needs/ 